\title{
MEASUREMENT OF ENVIRONMENTALLY SUSTAINABLE GROWTH OF AGRICULTURE IN TERMS OF TOTAL FACTOR PRODUCTIVITY
}

\begin{abstract}
Lina LAURAITIENĖ, Department of Applied Economics, Finance and Accounting, Faculty of Bioeconomy Development, Vytautas Magnus University. K. Donelaičio g. 58, LT-44248 Kaunas, Lithuania, lina.lauraitiene@ vdu.lt (corresponding author) Vlada VITUNSKIENĖ, Department of Applied Economics, Finance and Accounting, Faculty of Bioeconomy Development, Vytautas Magnus University. K. Donelaičio g. 58, LT-44248 Kaunas, Lithuania, vlada.vitunskiene@ @du.lt

The economic growth has resulted in the depletion of natural resources and degradation of ecosystems. Therefore, the environmentally sustainable growth was accepted as a new model for economy. The idea of environmentally sustainable growth has been widely discussed not only by experts in environmental economics, but also in the international and national policy scene. However, the measurement of environmentally sustainable growth still remains a challenge, especially in agriculture. This article aims to provide an overview of detailed information on adaptation of total factor productivity (TFP) for the measurement of environmentally sustainable growth in agriculture. A method of literature overview was used. Our findings indicate that there are different approaches for performing environmentally sustainable growth measurement in agriculture, and the total factor productivity (TFP) and its modifications are most commonly used indicators in last years. Green TFP growth or similar environmentally related its modifications are measured by growth accounting, data envelopment analysis and stochastic frontier analysis methods.
\end{abstract}

Keywords: environmentally sustainable growth, green growth, agriculture.

\section{INTRODUCTION}

Recently, the concept of environmentally sustainable growth, green growth, environmentally sustainable economic growth and ecologically sustainable growth has attracted much attention in the international and national policy scene. The guidelines for environmentally sustainable growth can be followed since 1987 Brundtland report. The key issues of environmentally sustainable growth were first set by the 5th Ministerial Conference on Environment and Development in Asia and the Pacific of the Economic and Social Commission for Asia and the Pacific of the United Nations Economic and Social Council in 2005. In this conference, environmentally sustainable growth was proposed as a way to seek for further economic growth with respect to environmental sustainability, without putting significant pressure on environmental capacity and without compromising environmental sustainability. The green growth considered as an orientation of sustainable development (UN Economic..., 2005). In the Rio+20 Conference on Sustainable Development in 2012, the green growth emerged as a central theme, and the "green economy" and "sustained economic growth" started to be considered as a way of sustainable development (Hickel, Kallis, 2020). Although Jacobs (2012) claimed that the "green economy" was rarely heard before 2008. As a result, various terms such as environmentally sustainable growth, green growth, green economy, green jobs, green economic growth and other are gaining popularity in the political and community space (Vavouras, 2011).

Literature overview shows that there is no single recognized and commonly used definition of environmentally sustainable growth. There are several equivalents of this concept, for example, environmentally sustainable growth, green growth, environmentally sustainable economic growth, ecologically sustainable growth, including green growth, genuine green growth, green economy, green new deal, low-carbon growth etc. Some concepts were used as synonims the others as separate concepts (Kim, Lee, 2017). Interactive Terminology for Europe (2021) gives preference to concept of environmentally sustainable growth which also is used in this study. Jacobs (2012) argues that sustainable environmental growth contributes not only to economic growth but also ensures environmental protection and sustainable use of natural resources. Consequently, the idea of environmentally sustainable growth has emerged as a dominant policy response to environmental crises. However,

Copyright ( $) 2021$ The Authors. Published by Vytautas Magnus University. This is an open-access article distributed under the terms of the Creative Commons Attribution License (CC BY 4.0), which permits unrestricted use, distribution, and reproduction in any medium, provided the original author and source are credited. 
according to Stoknes and Rockström (2018), the notion of environmentally sustainable growth is still notoriously vague and elusive. Moreover, the most common definition of environmentally sustainable growth focuses on environmental and economic issues (Jacobs, 2012) while social issues are only the result of the integration of environmental and economic objectives and their implementation (Kasztelan, 2017; OECD, 2014). Finally, the definition of environmentally sustainable growth does not explain how green growth can be measured. According to Stoknes and Rockström (2018), there is a lack of simple and clear indicators of whether economic growth at different scales is green enough. This is the relevance of environmentally sustainable growth assessment analysed in academic literature.

Along with the development of initiatives regarding environmentally sustainable growth a necessity to develop methods for its evaluation appeared (Kasztelan, 2017). There are different approaches for performing environmentally sustainable growth measurement in agriculture: (i) a framework for measuring green growth by including its key elements (e.g. production, environment and consumption) and its corresponding indicators (OECD, 2014; Kasztelan et al., 2019); and (ii) development of measures in terms of productivity, e.g. total factor productivity (TFP) and its modifications as the most commonly used indicators in the last years (Obst, Eigenraam, 2017; Xu et al., 2019; Fang et al., 2021; Zhong et al., 2021; Zhao, 2021; Coli, Colucci, 2021; etc.). This study aims to provide an overview of detailed information on adaptation of total factor productivity (TFP) indicator for the measurement of environmentally sustainable growth in agriculture based on the available academic literature.

\section{MATERIALS AND METHODS}

Literature overview method was used in this study to obtain information related to environmentally sustainable growth which includes both the economic (gross value added GVA, labour and produced capital) and environmental (natural capital and pollution) aspects of growth performance in agriculture. According to Snyder (2019) literature overviews are foundation for all types of research, due to the fact that literature overview may be the best methodological tool to identified a topic, to provide an overview of a relevant issue or research problem. Keywords were used as a most common method of identifying literature (Cronin et al., 2008).

The keywords used in this manuscript fell into the following two categories:

(i) growth related keywords such as environmentally sustainable growth, green growth and environmentallyadjusted growth in agriculture; and

(ii) growth measures related keywords such as green total factor productivity, environmental total factor productivity and environmentally adjusted multifactor productivity growth.

In the measurement methodology of the environmentally sustainable growth, terms "total factor productivity" (TFP) and "multifactor productivity" (MFP) often used as synonyms (Lee, Xuan, 2019; Peneder, Rammer, 2018). In this article, both TFP and MFP are considered as similar in terms of environmentally sustainable growth measure.

\section{RESULTS AND DISCUSSIONS}

The results of the literature review show that the discussion on environment versus growth continues to the recent day (Antal, van den Bergh, 2016; Sun et al., 2020), therefore the measurement method that incorporates environmental externalities is imperative in further agricultural growth accounting. According to Xu et al. (2019), agricultural productivity may be measured by three methods categories: (i) growth accounting method; (ii) data envelopment analysis (DEA); and (iii) stochastic frontier analysis (SFA). The first category of research uses growth accounting method that can be divided into algebraic index and Solow residual. However, algebraic index method only considers the market of desirable output and ignores undesirable output (Yang, Xue, 2017) such as greenhouse gas (GHG) emissions. Meanwhile, the Solow residual method is better compared to the algebraic index method (Wang, et al., 2021). The second category of research uses data envelopment analysis (DEA). According to Li et al. (2021), Zhong et al. (2021) and Xu et al. (2019), this nonparametric method is used to analyse the changes in agricultural productivity and it can deal with multiple input and output variables. Moreover, the DEA does not require assumptions about the functional form of production functions (Han et al., 2018). Finally, the third category of research uses stochastic frontier analysis (SFA) for measurement of agricultural productivity. According to Zhong et al. (2021) and Wang et al. (2021), this kind of method needs to set up a specific production function form.

Table 1 illustrates the modifications of total factor productivity (TFP) indicators used for measuring of environmentally sustainable growth in agriculture.

Table 2 illustrates the variables used for the environmentally modified TFP measurement. Based on literature overview, the explanatory variables are the output and input data used in the process of calculating agricultural productivity. In terms of output, the specificity of agriculture is joint multioutput production (Shumway et al., 1984; Asunka, et al., 1996), i.e. the marketable food and fibre produces jointly with non-marketed negative externalities and public goods (Anderson, 2000). In this regard, agriculture produces desirable outputs such as crops and livestock products, and generates undesirable outputs such as carbon emissions and polluted water, air and soil (Han et al., 
2018; Xu et al. 2019). The value of gross agricultural output is most commonly used variable in TFP analysis as the desired agricultural production output, while crops and livestock production, value added or output value of the primary industry (agriculture, forestry and fishery) is used in several cases as well. Agricultural carbon emissions as the undesired agricultural production output are included in many cases of the TFP analysis.

Table 1. Literature overview of the agricultural TFP / MFP indicators for measure of the environmentally sustainable growth in agriculture

\begin{tabular}{|l|l|l|}
\hline \multicolumn{1}{|c|}{ Author (s) } & \multicolumn{1}{|c|}{ Measures } & \multicolumn{1}{c|}{ Environmentally adjusted productivity methods } \\
\hline $\begin{array}{l}\text { Fang et al. (2021); } \\
\text { Zhong et al. (2021) }\end{array}$ & $\begin{array}{l}\text { Agricultural green total factor productivity } \\
\text { (AGTFP) }\end{array}$ & $\begin{array}{l}\text { Global-Malmquist-Luenberger (SBM-GML) index; } \\
\text { Metafrontier Malmquist-Luenberger (MML) index } \\
\text { model based on directional distance function }\end{array}$ \\
\hline Xu et al. (2019) & Green total factor productivity index (GTFPI) & $\begin{array}{l}\text { Global Malmquist-Luenberger (GML) index, Slacks- } \\
\text { Based Measure (SBM) Directional Distance Function }\end{array}$ \\
\hline $\begin{array}{l}\text { Nanere et al. (2007); } \\
\text { Han et al. (2018) }\end{array}$ & $\begin{array}{l}\text { Agricultural environmental total factor } \\
\text { productivity (AETFP) }\end{array}$ & $\begin{array}{l}\text { Fisher index; } \\
\text { Metafrontier Malmquist-Luenberger (MML) } \\
\text { productivity index using the DEA method }\end{array}$ \\
\hline Li et al. (2021) & Sustainable agricultural total factor productivity & DEA-Malmquist index \\
\hline Ang, Dakpo (2018) & Environmental total factor productivity index & Färe-Primont index, DEA \\
\hline Kimura, Sauer (2015) & $\begin{array}{l}\text { Environmentally adjusted multifactor } \\
\text { productivity index }\end{array}$ & Fisher productivity index \\
\hline $\begin{array}{l}\text { Hughes, et al. (2019); } \\
\text { Zhao (2021) }\end{array}$ & Climate adjusted total factor productivity & $\begin{array}{l}\text { Micro-simulation model, } \\
\text { Fisher index }\end{array}$ \\
\hline Coli, Colucci (2021) & $\begin{array}{l}\text { Total factor productivity index adjusted for } \\
\text { greenhouse gas emissions }\end{array}$ & Malmquist index, DEA \\
\hline
\end{tabular}

Source: Own composition

Table 2. Literature overview of the variables used in the agricultural TFP for measure of the environmentally sustainable growth in agriculture

\begin{tabular}{|c|c|c|c|c|c|c|c|c|c|c|c|c|c|}
\hline Variables of output and input & 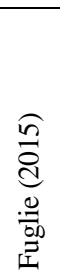 & 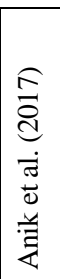 & 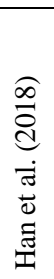 & 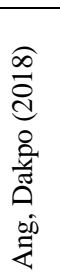 & 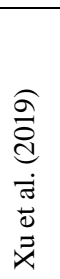 & 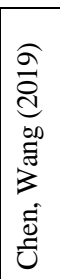 & 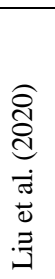 & 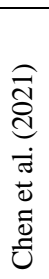 & 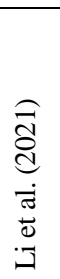 & 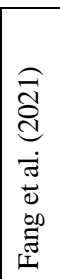 & 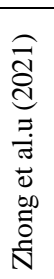 & 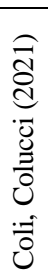 & 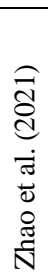 \\
\hline \multicolumn{14}{|l|}{ Desirable outputs: } \\
\hline Value of gross agricultural output & + & + & + & + & + & & & & & & + & & \\
\hline Added value of the primary industry & & & & & & & & & + & & + & + & \\
\hline Output value of the primary industry & & & & & & + & & + & & + & & & \\
\hline Corn yield & & & & & & & + & & & & & & \\
\hline Crops and livestock production & & & & & & & & & & & & & + \\
\hline \multicolumn{14}{|l|}{ Undesirable outputs: } \\
\hline Agricultural carbon emissions & & & + & + & + & + & + & + & & & + & + & \\
\hline Non-point source pollutant emissions into water & & & + & & & & & & & & & & \\
\hline \multicolumn{14}{|l|}{ Inputs: } \\
\hline Agricultural labour & + & + & + & + & + & + & & + & + & + & + & + & + \\
\hline Agricultural land & + & + & + & + & + & + & & & + & + & + & + & + \\
\hline Machinery & + & + & + & + & + & + & + & + & + & + & + & + & + \\
\hline Fertilizer & + & + & + & + & + & + & + & + & + & + & + & + & + \\
\hline Pesticide / chemicals & & & & + & + & & + & & & & & & \\
\hline Livestock capital (farm animals) & + & + & & + & + & + & & & & & & + & \\
\hline Irrigation & & + & & & + & + & & & & + & & & \\
\hline Animal feed & + & & & + & + & & & & & & & & \\
\hline Seed & & & & & & & + & & & & & & + \\
\hline Agricultural energy & & & & & & & & + & & & & & \\
\hline Electricity & & & & & & & & & & + & & & \\
\hline Agricultural plastic film & & & & & + & & & & & & & & \\
\hline Other materials & & & & & & & & & & & & & + \\
\hline Services & & & & & & & & & & & & & + \\
\hline
\end{tabular}

Both desirable and undesirable agricultural outputs result from farm lands, animals and other fixed and variable inputs of production. There are some differences in the list of variable inputs used in TFP analysis as showed in the table 2. In terms of production materials, the fertilizer input are included in the TFP analysis in many cases, while energy, pesticide, animal feed, seed, plastic film are used in some cases. 
Table 2 illustrates that most studies use four type of inputs as an explanatory variable to measure agricultural TFP. In terms of the labour input, the number of adults (males and females) who are economically active in agriculture (Fuglie, 2015) or the number of economically active persons engaged in primary industry (Coli, Colucci, 2021) are used. According to Kimura, Sauer (2015), the hired employees are taken as the labour input variable. Different categories of land are used in the analysis as a land input variable such as: total land areas used in agricultural production (Kimura, Sauer, 2015; Li et al., 2021; Zhong et al., 2021); or an area of some sown crops (Anik et al., 2017; Fang, et al., 2021); or more specific agricultural land measures in hectares of rainfed cropland equivalents (Ang, Dakpo, 2018). The irrigation input is expressed in terms of effective irrigation area. This kind of input is estimated as the ratio of total area equipped for irrigation and total utilised area (Anik et al., 2017; Xu et al., 2021; Chen, Wang, 2019; Fang et al., 2021)

In terms of the fixed capital input, the power of agricultural machinery as agricultural mechanical input and livestock capital are used in the analysis. Livestock input is expressed by the number of large animals at the end of the year. Some authors used only cattle (Ang, Dakpo, 2018), some - cattle and buffaloes (Anik et al., 2017), and some - cattle, horses, donkeys, mules and camels (Chen, Wang, 2019) for expression of livestock input.

The animal feed, seed, agricultural energy or electricity and plastic film, etc. are used in TFP analysis as terms a materials input. The input of agricultural fertilizers that may be measured as pure amount including nitrogen and phosphorus fertilizers ( $\mathrm{Li}$ et al., 2021) or nitrogen, phosphorus, potassium and compound fertilizers (Anik et al., 2017; Fuglie, 2015; Zhong et al., 2021) used in agricultural production. Some authors (Chen et al., 2021) claim that agricultural energy input expressed in terms of whole energy, the others (Fang et al., 2021) that only electricity. Moreover, some countries have very specific input such as agricultural plastic film. According to Zong et al. (2021), plastic mulch is widely used in agriculture to increase crop yields and improve water use efficiency. However, the residual plastic fragments in utilised area increase environmental pollution. To summarize, the choice of output and input variables for environmentally modified TFP or MFP in agricultural analysis depends on the subject being examined and on the availability of data in used database.

\section{CONCLUSIONS}

Over recent years the concepts of environmentally sustainable growth, green growth and other similar growth concepts related to environmental impact has attracted much of the attention in the academic literature. However, all of these concepts have emerged in international policy discourse. The environmentally sustainable growth is proposed as a way to seek for further economic growth with respect to environmental sustainability, without putting significant pressure on environmental capacity and without compromising environment sustainability in the 5th Ministerial Conference on Environment and Development in Asia and the Pacific of the Economic and Social Commission for Asia and the Pacific of the United Nations Economic and Social Council in 2005. The green growth is considered as a way of communicating environmentally sustainable growth. In the Rio+20 Conference on Sustainable Development, green growth emerged as a central issue.

Along with the development of political initiatives regarding environmentally sustainable growth and development of its theory a necessity to develop methods for its evaluation appeared. The findings of this research suggest that, in terms of TFP growth, environmentally sustainable growth of agriculture is measured by growth accounting, data envelopment analysis and stochastic frontier analysis methods. Besides, the use of the methods and the choice of the explanatory variables depend on data availability. An increasing number of studies have sought to measure the productivity indicators for measuring the environmentally sustainable growth in agriculture, especially in 2021 .

The OECD (2014) is exploring ways of how to include undesirable output and natural resources as inputs in the measurement of adjusting multifactor productivity in agriculture. There are argued that there is a lack of agreement among experts in terms of research related to measuring green agricultural productivity. Moreover, the present studies are only not on a methodological approach but also on a practical approach.

\section{REFERENCES}

1. Anderson, K. 2000. Agriculture's 'multifunctionality' and the WTO. Australian Journal of Agricultural and Resource Economics, Vol. 44(3), pp. 475-494. https://doi.org/10.1111/1467-8489.00121

2. Ang, F., Dakpo, H. 2018. Sustainable Intensification in agriculture? A global assessment (No. 2133-2018-5421).

3. Anik, A., Rahman, S., Sarker, J. 2017. Agricultural productivity growth and the role of capital in South Asia (1980-2013). Sustainability, Vol. 9, 470. https://doi.org/10.3390/su9030470

4. Antal, M., Van Den Bergh, J. C. 2016. Green growth and climate change: conceptual and empirical considerations. Climate Policy, Vol. 16(2), pp. 165-177. https://doi.org/10.1080/14693062.2014.992003

5. Asunka, S., Shumway, C. R. 1996. Allocatable fixed inputs and jointness in agricultural production: more implications. Agricultural and Resource Economics Review, Vol. 25(2), pp. 143-148. https://doi.org/10.1017/S1068280500007802

6. Chen, Y., Miao, J., Zhu, Z. 2021. Measuring green total factor productivity of China's agricultural sector: A three-stage SBMDEA model with non-point source pollution and CO2 emissions. Journal of Cleaner Production, Vol. 318, 128543. https://doi.org/10.1016/j.jclepro.2021.128543

7. Chen, Y., Wang, F. 2019. Environmentally-adjusted Analysis of Total Factor Productivity of Chinese Agriculture. 
8. Coli, A., Colucci, D. 2021. Total Factor Productivity Growth in Agriculture, Adjusted for Greenhouse Gas Emissions: Trends in Developed and Developing Countries over the 1992-2016 period.

9. Cronin, P., Ryan, F., Coughlan, M. 2008. Undertaking a literature review: a step-by-step approach. British Journal of Nursing, Vol. 17(1), pp. 38-43. https://doi.org/10.12968/bjon.2008.17.1.28059

10. Fang, L., Hu, R., Mao, H., Chen, S. 2021. How crop insurance influences agricultural green total factor productivity: Evidence from Chinese farmers. Journal of Cleaner Production, Vol. 321, 128977. https://doi.org/10.1016/j.jclepro.2021.128977

11. Fuglie, K. 2015. Accounting for growth in global agriculture. Bio-based and Applied Economics, Vol. 4(3), pp. 201-234.

12. Han, H., Zhong, Z., Wen, C., Sun, H. 2018. Agricultural environmental total factor productivity in China under technological heterogeneity: characteristics and determinants. Environmental Science and Pollution Research, Vol. 25(32), pp. 32096-32111. https://doi.org/10.1007/s11356-018-3142-4

13. Hickel, J., Kallis, G. 2020. Is green growth possible?. New Political Economy, Vol. 25(4), pp. $469-486$. https://doi.org/10.1080/13563467.2019.1598964

14. Hughes, N., Soh, W. Y., Boult, C., Lawson, K., Donoghoe, M., Valle, H., \& Chancellor, W. 2019. Farmpredict: A microsimulation model of Australian farms. The Australian Bureau of Agricultural and Resource Economics and Sciences (ABARES). Working Paper, Canberra, September.

15. Interactive Terminology for Europe. 2021. European Union terminology. https://iate.europa.eu/home

16. Jacobs, M. 2012. Green growth: economic theory and political discourse. Centre for climate change economics and policy working paper, 108.

17. Kasztelan, A., Nowak, A., Hawlena, J. 2019. Green growth in agriculture in the European Union: myth or reality? European Research Studies Journal, Vol. XXII (4), pp. 35-48. https://doi.org/10.35808/ersj/1495

18. Kasztelan, A. 2017. Green growth, green economy and sustainable development: terminological and relational discourse. Prague Economic Papers, Vol. 26 (4), pp. 487-499. https://doi.org/10.18267/j.pep.626

19. Kasztelan, A., Nowak, A. 2021. Construction and Empirical Verification of the Agri-Environmental Index as a Tool for Assessing the Green Performance of Agriculture. Energies, Vol. 14 (1), 45. https://doi.org/10.3390/en14010045

20. Kim, Y. S., Lee, M. K. 2017. Developing a Tool to Assess Green Growth Potential at a National Level. Korea and the World Economy, Vol. 18(S1), pp. 47-82.

21. Kimura, S., Sauer, J. 2015. Dynamics of dairy farm productivity growth: Cross-country comparison. OECD. Food, Agriculture and Fisheries Papers, No. 87, OECD, Publishing, Paris. https://doi.org/10.1787/5jrw8ffbzf71-en

22. Lee, J.W., Xuan, Y. 2019. Effects of technology and innovation management and total factor productivity on the economic growth of China. The Journal of Asian Finance, Economics, and Business, Vol. 6(2), pp. 63-73. https://doi.org/10.13106/jafeb.2019.vol6.no2.63

23. Li, J., Chen, J., Liu, H. 2021. Sustainable Agricultural Total Factor Productivity and Its Spatial Relationship with Urbanization in China. Sustainability, Vol. 13(12), 6773. https://doi.org/10.3390/su13126773

24. Liu, P., Fang, Z., Gong, C. 2020. Variation in total factor productivity of corn in 19 main producing areas under the constraint of carbon emissions. International Journal of Sustainable Development and Planning, Vol. 15(5), pp. 775-780. https://doi.org/10.18280/ijsdp.150520

25. Nanere, M., Fraser, I., Quazi, A., D’Souza, C. 2007. Environmentally adjusted productivity measurement: An Australian case study. Journal of Environmental Management, Vol. 85 (2), pp. 350-362. https://doi.org/10.1016/j.jenvman.2006.10.004

26. Obst, C., Eigenraam, M. 2017. environmental accounting. New Directions in Productivity Measurement and Efficiency Analysis: Counting the Environment and Natural Resources, 151.

27. OECD. 2011. Towards green growth: monitoring progress. OECD indicators.

28. OECD. 2014. Green Growth Indicators for Agriculture: A Preliminary Assessment, OECD Green Growth Studies, OECD Publishing.

29. Peneder, M., Rammer, C. 2018. Measuring Competitiveness. ZEW-Gutachten und Forschungsberichte.

30. Shumway, C. R., Pope, R. D., Nash, E. K. 1984. Allocatable fixed inputs and jointness in agricultural production: implications for economic modeling. American Journal of Agricultural Economics, Vol. 66(1), pp. 72-78. https://doi.org/10.2307/1240617

31. Snyder, H. 2019. Literature review as a research methodology: An overview and guidelines. Journal of Business Research, Vol. 104, pp. 333-339. https://doi.org/10.1016/j.jbusres.2019.07.039

32. Stoknes, P. E., Rockström, J. 2018. Redefining green growth within planetary boundaries. Energy Research \& Social Science, Vol. 44, pp. 41-49. https://doi.org/10.1016/j.erss.2018.04.030

33. Sun, Y., Ding, W., Yang, Z., Yang, G., Du, J. 2020. Measuring China's regional inclusive green growth. Science of the Total Environment, Vol. 713, 136367. https://doi.org/10.1016/j.scitotenv.2019.136367

34. UN Economic and Social Council. 2005. Key developments and activities at the regional level: Managing Globalization. Report on the outcomes of the fifth Ministerial conference on Environment and Development in Asia and the Pacific. Economic and Social Commission for Asia and the Pacific. E/ESCAP/1337 4 May 2005.

35. Vavouras, I. 2011. From sustainable development to green growth: The abandonment of the social character of development. Social Cohesion and Development, Vol. 6(1), pp. 27-35. https://doi.org/10.12681/scad.8972

36. Wang, F., Wu, J., Wu, M., Zheng, W., Huang, D. 2021. Has the Economic Structure Optimization in China's Supply-Side Structural Reform Improved the Inclusive Green Total Factor Productivity? Sustainability, Vol. 13(22), 12911. https://doi.org/10.3390/su132212911 
37. Wang, Y., Sun, X., Wang, B., Liu, X. 2020. Energy saving, GHG abatement and industrial growth in OECD countries: green productivity approach. Energy, Vol. 194, 116833. https://doi.org/10.1016/j.energy.2019.116833

38. Xu, X., Huang, X., Huang, J., Gao, X., Chen, L. 2019. Spatial-temporal characteristics of agriculture green total factor productivity in China, 1998-2016: based on more sophisticated calculations of carbon emissions. International Journal of Environmental Research and Public Health, Vol. 16(20), 3932. https://doi.org/10.3390/ijerph16203932

39. Yang, J. L., Xue, J. L. 2017. The Research on the Green Productivity of High-carbon Industries in Resource-originated Region. In Proceedings of 2017 4th International Conference on Education, Management and Computing Technology (ICEMCT 2017), pp. 1611-1620. Atlantis Press. https://doi.org/10.2991/icemct-17.2017.343

40. Zhao, S., Chancellor, W., Jackson, T., Boult, C. 2021. Productivity as a measure of performance: ABARES perspective. Farm Policy J., No. 18(1).

41. Zhong, S., Li, Y., Li, J., Yang, H. 2021. Measurement of total factor productivity of green agriculture in China: Analysis of the regional differences based on China. PLoS ONE, Vol. 16(9). https://doi.org/10.1371/journal.pone.0257239

42. Zong, R., Han, H., Li, Q. 2021. Grain yield and water-use efficiency of summer maize in response to mulching with different plastic films in the North China Plain. Experimental Agriculture, Vol. 57(1), pp. 33-44. https://doi.org/10.1017/S001447972100003X 